\title{
WELDING AS A PROCESS IN SHIP CONSTRUCTION
}

\author{
BY S. V. GOODALL
}

\section{Abstract of Paper}

The paper points to the necessity for a reduction in the cost of shipbuilding, and as riveting is one of the most expensive items of construction the substitution of welding for riveting would decrease the cost of construction considerably. A brief review is given of what has been done in substituting welding for riveting, and to the limited extent to which electric welding has been tried it has been found successful. Lloyd's Register is prepared to classify electrically-welded vessels subject to certain provisions, but shipbuilders have not as yet adopted welding to a large extent for the reason, in the author's opinion, that they know that welds are lacking in uniformity and it is impossible to tell when a joint is good or bad. The author believes that the correct method of approaching the problem of electric welding is first to obtain workmen who are thoroughly trained and skilled and the suggestion is made that only certified men should be employed at this work. From the welding of minor parts the process could be advanced to more important members until eventually a ship would be produced in which both the processes of welding and riveting would be utilized in whatever proportions would attain maximum economy of construction.

$\mathrm{D}$ URING the war, economy of time in the production of all that was needed to terminate hostilities successfully was of paramount importance. Economy in first cost and maintenance was relatively unimportant. If the production of a ship, an aeroplane, a tank or any implement of war could hasten the end by a single day it was more economical, in the long run, to place that implement on service today instead of tomorrow, even at a somewhat higher cost, for the shortening of the struggle by that single day meant a saving of many lives and millions of dollars. But besides being called upon to save time the engineer was forced to economize in labor and to use unskilled workmen. . During the war gas welding and electric welding have been enormously developed as processes in the manufacture of munitions of all kinds. It goes without saying, therefore, that in these processes engineers found a means of saving time and labor.

Now that hostilities have ceased, economy in first cost and 
maintenance becomes once again of primary importance, economy of time and labor being of value only in so far as it results in cheaper production. This is particularly true of shipbuilding. Every shipbuilder should now carefully review the various items of cost in the production of a ship, and while he may devote his energies to a reduction all round, he will, if he be wise, give greatest attention to a reduction in the cost of the most expensive of those items. Riveting is this most expensive item. It has been estimated that the labor cost of riveting is about 40 per cent of the total labor cost of building the structure of a steel cargo carrier, while the labor cost of shopwork on structural material is about 15 to 20 per cent. During the past few years considerable attention has been given to improvements in shopwork and it is unlikely that much economy can be effected in this direction. Can anything be done to lower the cost of riveting? The advocates of welding reply "Yes, by a wide substitution of welding for riveting." This is a claim that should not be lightly placed on one side but carefully and critically examined by all shipbuilders. To offer some slight assistance in that examination this paper has been prepared.

Gas welding has been used in shipyards for many years, resulting in economy in the production of staple angles and similar smith work. It has found a wide field in the construction of light fittings, being more particularly of value for thin work than for heavy plating. As it may be considered that gas welding has now found its level as a shipbuilding process, this subject is not enlarged upon; the little that is said must not be taken as a measure of its importance.

Electric welding as a science and art has been dealt with at this meeting. As a process in shipbuilding much literature on the subject already exists, the most comprehensive papers known to the author being that by Mr. W. S. Abell, Chief Ship Surveyor of Lloyd's Register, read before the British North East Coast Institution of Shipbuilders and Engineers at Newcastle in November, 1918, and that by Mr. H. Jasper Cox, read before the Society of Naval Architects and Marine Engineers at Philadelphia in the same month. The author makes no attempt, even if he were capable of doing so, of giving such detailed particulars of the subjects as can be found in these and other papers, but he does attempt to speak, as a shipbuilder to shipbuilders, plainly and impartially, without ex- 
travagant claims, and with some little knowledge of experience so far obtained, on the present position of the process and the policy which should be adopted, looking towards the future.

It is very well known that electric welding has been of great value on repair work, particularly during the war. Ships that would otherwise have been laid up for weeks while new castings were obtained, old plates removed and replaced by new, \&c., \&c., have been rapidly repaired and returned to service. If the ship repairer finds a process of such value the shipbuilder should at least inquire whether it would not be of some value to him.

The Classification Societies have sanctioned the use of electric welding for a considerable amount of work of little importance so far as structural strength is concerned. The Welding Committee of the Emergency Fleet Corporation has found by actual experience that a labor saving of at least 60 per cent results from the substitution of arc welding for riveting on these minor parts of a ship; and Mr. J. H. Anderton has estimated that a saving in time of 70 per cent was effected at Hog Island.

Lloyd's Register of Shipbuilding is prepared to classify an electrically welded vessel, subject to the notations, "Experimental" and "Electrically Welded," and provided the builders conform to certain rules. This decision was reached after an extensive and exhaustive series of trials. Before any electric welding system can be employed on a vessel which Lloyd's will classify, specimens welded according to that system must satisfy tests, which, at first sight, appear almost prohibitive in their severity, but an electrically welded ship is now under construction at Cammell Laird's, England, to be classified by Lloyd's, who have approved the employment of the QuasiArc Company's system in its construction. This is a small vessel about 150 feet long, with plating generally $3 / 8$ to $1 / 2$ inch in thickness.

Electric welding work carried out by the British Admiralty has been described in a paper read by the author before the Engineers' Club of Philadelphia, in July, 1918. Since that time valuable experience with this work on service has been obtained. The arc welded barge has been satisfactory. The cost of material, electric current and labor for this vessel was $£ 301$ (\$1463) as compared with $£ 389(\$ 1892)$ for the cost of riveting, caulking and drilling on a similar barge constructed at the same yard. The vessel was designed to be rivetless 
as a demonstration of arc welding; it was found that greater economy would result if certain parts such as beams to frames, floor plates to angles, etc., were riveted.

As the plating of this barge is thin and the stresses to which it is subjected are not comparable to those which a large seagoing ship is called upon to withstand, greater interest attaches to experience with other British ships in which are welding has been employed by the Admiralty, particularly to those where the work has been comparatively heavy. It must be said at once that failures of welded joints have been reported, although the number of such failures has not been large considering the amount of work that has been done, the lack of experience, the dearth of skilled operators, and the radical change in method. The Admiralty authorities, however, consider it wise, pending further experience, to defer the adoption of electric welding for those parts of the structure subjected to high complex stresses unless the work can be so tested as to demonstrate exactly that such stresses can be safely carried.

Lap welding has been more satisfactory than butt welding and the latter has been, for the present, discarded for all important work where the plating is $3 / 8$-inch or more in thickness. It is hoped that this situation will not last long, for it is in butt welding that the greatest gain from the use of this process may be expected, and lap joints necessitate a certain amount of overhead welding which is difficult and unreliable.

While the above briefly sums up the present position of electric welding as a process in shipbuilding it may be fairly asked why - if the Classification Societies permit the process on minor parts; if Lloyd's are prepared, subject to certain conditions to classify an electrically welded ship; if the British Admiralty has employed the process to a considerable extent; if American railroads have used welding extensively on locomotives-why has not electric welding been adopted in American shipyards to a greater extent than it has been up to the present? There is no doubt that during the war, shipbuilders in the United States were too hard pressed to be able to give much time and thought to the development of an entirely new process in ship construction. That is one reason. Inate conservatism is another. But the real reason, in the author's opinion, is that shipbuilders know that, at present, welds are lacking in uniformity, and it is not yet possible to tell when the welded joint is good or bad. Hence they hang back and the author commends their wisdom. 
It is far better that the first ocean-going electrically welded ship should be on service three years hence with every joint sufficiently sound-universally accepted as a thorough successthan that it should be at the bottom of the sea tomorrow because, while 999 joints were sound, one went astray.

How can this certainty that every joint will be efficient be ensured? While the electrical engineer and the metallurgist can assist the shipbuilder to solve this problem, there is much that he himself can do.

In the first place he must realize the importance of employing only thoroughly skilled and experienced workmen and he should call in the manufacturers of electric welding apparatus to assist him. The latter, for their own protection and the welfare of the industry on which they rely, should see to it that no ship should be allowed to be built with some of the thoroughly rotten work done by absolutely unskilled welders that the author has seen in this country. It is strongly urged that steps should be taken at once to establish welding as a skilled trade and only certified men should be allowed to be employed. All the reports that have been seen on good and bad welds lay stress upon the fact that, in general, defects are mechanical and not an inherent feature of the process. Skilled men working under an experienced foreman would know, for example, that clean surfaces are necessary for good work, they would quickly learn what types of joint are made with ease, in what portions of a ship welding is cheap or where it is unreliable, and from their ranks should be drawn the draughtsmen who will design in detail the welded vessel of the future. The Electric Welding Committee of the Emergency Fleet Corporation has spent much time and thought on the attempt to discover a practical nondestructive method of testing welds. While such a method of testing would be very valuable, it is the author's opinion, that when only welders of proved skill are employed under experienced supervision, such tests would be no more necessary than a shear test on every rivet of a riveted ship; but, so long as such welders are not available the shipbuilder will look askance at a process that may be good generally but may have weak spots of which he is ignorant.

Secondly, after he has trained a reliable staff of welders on work of minor importance the shipbuilder must devote his attention to the best method of assembly of large parts, so that he may feel reasonably sure that every joint of the finished struc- 
ture possesses the qualities which his welders can with certainty produce in test pieces. From the very outset it has been realized that this is a difficult problem which can be solved only by patient trial and experience. Present opinion at the British Admiralty is that the only satisfactory method is by the use of closing bolts as for riveted joints. In the case of the Richborough barge a certain amount of buckling resulted on the outboard edge of the garboard strakes after these plates had been welded to the keel plates, but this was removed when the bilge plates were put into position and bolted up. In the heavier work it may be that, buckling of plates being impossible, the internal stresses set up in welding were the causes of the failures that occurred. It is understood that this method is being adopted at Cammell Laird's but, again the plating of this vessel is not very heavy and it is definitely known that this feature received most careful consideration from the very beginning. In the author's opinion this difficulty is by no means insuperable. Its existence should spur on the progressive shipbuilder, for when he has solved the problem, by that much will he be ahead of his competitors.

In the third place it appears to be the fact that shipbuilding steel in Great Britain is more adapted to welding than shipbuilding steel in this country, and the former is also more regular in its qualities. If shipbuilders are satisfied that such is the case and are also convinced that electric welding has a great future in ship construction, they should take concerted action to ensure that steel producers supply the material best suited to their purpose.

So far the author has urged a careful survey of the possibilities of welding as a substitute for riveting only on the ground that the latter is the most costly item of labor on structural work and it behooves the shipbuilder to reduce that cost. But there are other advantages incidental to welding that must not be overlooked. A sound arc-welded joint is necessarily watertight and once such a joint with known efficiency can be made with certainty caulking is eliminated and the work of water-testing made easier. It must be admitted that, so far, the advantages anticipated in this direction have not been fully realized, but that they will be realized is only a matter of time, and it has already been fully demonstrated that welded joints, being stiffer, stand up better under test and there is no breaking away of the caulk such as is sometimes 
experienced with riveted connections under water pressure. Another advantage is a saving in steel due to the absence of rivet heads and the smaller width of laps and butt straps. Some advocates of welding claim that the labor of marking off, punching and assembling will be much reduced, more particularly by the adoption of spot-welding, but the author is bound to say that at present he is not a convert to the adoption of spot-welding for heavy ship work, it is his opinion that there are many difficulties ahead for those shipbuilders who attempt this form of welding and until those difficulties have been fairly and squarely met he hesitates to affirm that spot-welding will be found a valuable process in ship construction.

In conclusion, it is desired once again to place the subject before the shipbuilder in this light. The cost of ship construction must be reduced. A reduction in riveting is the most fruitful field for economy. Electric welding as a substitute has been tried to a limited extent and found successful. Classification Societies are prepared to accept the process, though at present the only vessels built or under construction are small. There are difficulties ahead but they do not appear insuperable. The best line of approach appears to be to build up a staff of thoroughly skilled welders, to gain experience by the adoption of welding on minor parts, to proceed cautiously in the extension of the process to more important members, not to expect a great saving in time and cost immediately, but to persevere, not necessarily towards the rivetless ship but towards a vessel in which the employment of both processes of riveting and welding is so adjusted that more riveting or more welding could only be done at greater cost. 